\title{
The Modigliani-Miller Propositions After Thirty Years
}

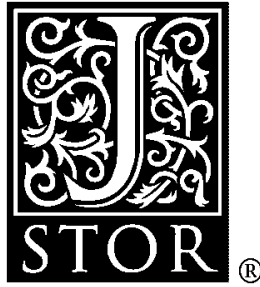

\author{
Merton H. Miller
}

The Journal of Economic Perspectives, Vol. 2, No. 4. (Autumn, 1988), pp. 99-120.

Stable URL:

http://links.jstor.org/sici?sici=0895-3309\%28198823\%292\%3A4\%3C99\%3ATMPATY\%3E2.0.CO\%3B2-V

The Journal of Economic Perspectives is currently published by American Economic Association.

Your use of the JSTOR archive indicates your acceptance of JSTOR's Terms and Conditions of Use, available at

http://www.jstor.org/about/terms.html. JSTOR's Terms and Conditions of Use provides, in part, that unless you have obtained prior permission, you may not download an entire issue of a journal or multiple copies of articles, and you may use content in the JSTOR archive only for your personal, non-commercial use.

Please contact the publisher regarding any further use of this work. Publisher contact information may be obtained at http://www.jstor.org/journals/aea.html.

Each copy of any part of a JSTOR transmission must contain the same copyright notice that appears on the screen or printed page of such transmission.

JSTOR is an independent not-for-profit organization dedicated to and preserving a digital archive of scholarly journals. For more information regarding JSTOR, please contact support@jstor.org. 


\title{
The Modigliani-Miller Propositions After Thirty Years
}

\author{
Merton H. Miller
}

$\mathbf{T}$

his issue of the Journal of Economic Perspectives appears on the 30th anniversary of the Modigliani-Miller propositions in "The Cost of Capital, Corporation Finance and the Theory of Investment," published in the American Economic Review, June 1958. The editors have invited me, if not to celebrate, at least to mark the event with a retrospective look at what we set out to do on that occasion and an appraisal of where the propositions stand today after three decades of intense scrutiny and often bitter controversy.

Some of these controversies can be now be regarded as settled. Our Proposition I, holding the value of a firm to be independent of its capital structure (that is, its debt/equity ratio) is accepted as an implication of equilibrium in perfect capital markets. The validity of our then-novel arbitrage proof of that proposition is also no longer disputed, and essentially similar arbitrage proofs are now common throughout finance. ${ }^{1}$ Propositions analogous to, and often even called, $\mathbf{M}$ and $\mathbf{M}$ propositions, have spread beyond corporation finance to the fields of money and banking, fiscal policy and international finance. ${ }^{2}$

\footnotetext{
${ }^{1}$ Examples include Cornell and French (1983) on the pricing of stock index futures, Black and Scholes (1973) on the pricing of options and Ross (1976) on the structure of capital asset prices generally. For other, and in some respects, more general proofs of our capital structure proposition, see among others, Stiglitz (1974) for a general equilibrium proof showing that individual wealth and consumption opportunities are unaffected by capital structures; Hirshleifer (1965) and (1966) for a state preference, complete-markets proof; Duffie and Shafer (1986) for extensions to some cases of incomplete markets and Merton (forthcoming) for a spanning proof.

${ }^{2}$ See, for example, Wallace (1981) on domestic open-market operations; Sargent and Smith (1986) on central bank foreign-exchange interventions; Chamley and Polemarchakis (1984) on government tax and borrowing policies; and Fama $(1980,1983)$ on money, banking and the quantity theory.
}

Merton H. Miller is Robert R. McCormick Distinguished Service Professor, Graduate School of Business, University of Chicago, Chicago, Illinois. 
Clearly Proposition I, and its proof, have been accepted into economic theory. Less clear, however, is the empirical significance of the MM value-invariance Proposition $I$ in its original sphere of corporation finance.

Skepticism about the practical force of our invariance proposition was understandable given the almost daily reports in the financial press, then as now, of spectacular increases in the values of firms after changes in capital structure. But the view that capital structure is literally irrelevant or that "nothing matters" in corporate finance, though still sometimes attributed to us (and tracing perhaps to the very provocative way we made our point), is far from what we ever actually said about the real world applications of our theoretical propositions. Looking back now, perhaps we should have put more emphasis on the other, upbeat side of the "nothing matters" coin: showing what doesn't matter can also show, by implication, what does.

This more constructive approach to our invariance proposition and its central assumption of perfect capital markets has now become the standard one in teaching corporate finance. We could not have taken that approach in 1958, however, because the analysis departed too greatly from the then-accepted way of thinking about capital structure choices. We first had to convince people (including ourselves!) that there could be any conditions, even in a "frictionless" world, where a firm would be indifferent between issuing securities as different in legal status, investor risk and apparent cost as debt and equity. Remember that interest rates on corporate debts were then in the 3 to 5 percent range, with equity earnings/price ratios - then the conventional measure of the "cost" of equity capital-running from 15 to 20 percent.

The paradox of indifference in the face of such huge spreads in the apparent cost of financing was resolved by our Proposition II, which showed that when Proposition I held, the cost of equity capital was a linear increasing function of the debt/equity ratio. Any gains from using more of what might seem to be cheaper debt capital would thus be offset by the correspondingly higher cost of the now riskier equity capital. Our propositions implied that the weighted average of these costs of capital to a firm would remain the same no matter what combination of financing sources the firm actually chose.

Though departing substantially from the then-conventional views about capital structure, our propositions were certainly not without links to what had gone before. Our distinction between the real value of the firm and its financial packaging raised many issues long familiar to economists in discussions of the "money illusion" and money neutrality. Even some of the particular "financial illusions" to which we were directing attention had themselves already been noted by others as we duly cited in our paper. These earlier statements, however, had, to our knowledge, given rise to no follow-up work. The only prior treatment similar in spirit to our own was by David Durand (1952), who, as it turned out, also became our first formal critic (Durand, 1959). He had proposed, though not proved, as one of what he saw as two polar approaches to valuing shares, that investors might ignore the firm's then-existing capital structure and first price the whole firm by capitalizing its operating earnings before interest and taxes. The value of the shares would then be found by subtracting 
out the value of the bonds. But he rejected this possibility in favor of his other extreme, which he believed closer to the ordinary, real world way of valuing corporate shares, in which investors capitalized the firm's net income after interest and taxes with only a loose, qualitative adjustment for the degree of leverage in the capital structure.

That we too did not dismiss the seemingly unrealistic approach of looking through the momentary capital structure to the underlying real flows may well trace to the macroeconomic perspective from which we had approached the problem of capital structure in the first instance. Our main concern, initially, was with the determinants of aggregate economic investment by the business sector. The resources for capital formation by firms came ultimately from the savings of the household sector, a connection that economists had long found convenient to illustrate with schematic national income and wealth $\mathrm{T}$-accounts, including, of course, simplified sectoral balance sheets such as:

\begin{tabular}{l|l}
\multicolumn{2}{c}{ Business Firms } \\
\hline \multicolumn{1}{c}{ Assets } & Liabilities \\
\hline $\begin{array}{l}\text { Productive } \\
\text { Capital }\end{array}$ & $\begin{array}{l}\text { Debts owed to households } \\
\text { Equity in firms owned } \\
\text { by households }\end{array}$
\end{tabular}

\begin{tabular}{c|c}
\multicolumn{2}{c}{ Households } \\
\hline Assets & Liabilities \\
\hline Debts of firms & $\begin{array}{c}\text { Household net } \\
\text { worth }\end{array}$ \\
Equity in firms &
\end{tabular}

Consolidating the accounts of the two sectors leads to the familiar national balance sheet:

\begin{tabular}{c|c} 
Assets & Liabilities \\
\hline $\begin{array}{c}\text { Productive } \\
\text { Capital }\end{array}$ & Household Net Worth
\end{tabular}

in which the debt and equity securities no longer appear. The value of the business sector to its ultimate owners in the household sector is thus seen clearly to lie in the value of the underlying capital. And by the same token, the debt and equity securities owned by households can be seen not as final, but only as intermediate assets serving to partition the earnings (and their attendant risks) among the many separate individual households within the sector.

Our value-invariance Proposition I was in a sense only the application of this macroeconomic intuition to the microeconomics of corporate finance; and the arbitrage proof we gave for our Proposition I was just the counterpart at the individual investor level of the consolidation of accounts, and the washing out of the debt/equity ratios at the sectoral level. In fact, one blade of our arbitrage proof had the arbitrager 
doing exactly that washing out. If levered firms were undervalued relative to unlevered firms, our arbitrager was called on to "undo the leverage" by buying an appropriate portion of both the levered firm's debt and its shares. On a consolidated basis, the interest paid by the firm cancels against the interest received and the arbitrager thus owned a pure equity stream. Unlevered corporate equity streams could in turn be relevered by borrowing on individual account if unlevered streams ever sold at a discount relative to levered corporate equity. That possibility of "homemade leverage" by individual investors provided the second and completing blade of our arbitrage proof of value invariance.

Our arbitrage proof drew little flak from those who saw it essentially as a metaphor - an expository device for highlighting hidden implications of the "law of one price" in perfect capital markets. But whether the operations we called arbitrage could in fact substitute for consolidation when dealing with real world corporations was disputed. Could investors, acting on their own, really replicate and, where required, wash out corporate capital structures? Even if they could not do so completely and immediately as in the formal proof, could they act completely enough and quickly enough to make the invariance proposition useful as a description of the central tendency in the real world capital market? These long-standing and still not completely resolved issues of empirical relevance of the MM propositions will be the primary focus in what follows here.

Three separate reasons (over and above the standard complaint that we attributed too much rationality to the stock market) were quickly offered by our critics for believing that individual investors could not enforce the corporate valuations implied by Propositions I and II. These lines of objection-relating to dividends, debt defaults, and taxes-each emphasized a different, distinctive feature of the corporate form of business organization; and each, in turn, will be reexamined here, taking full advantage of the hindsight of 30 years of subsequent research and events.

Before turning to these objections, however, it may be worth emphasizing at this point, while the sectoral tableaus are still near at hand to serve as a reminder, that our proposition that value was independent of capital structure at the individual firm level was never intended to suggest that the debt/equity ratio was indeterminate. At the firm level, there were clearly other costs of the various financial alternatives to be taken into account and we will get to some of these in due course. But even waiving the transaction and other second-order costs of financial packaging, the aggregate debt/equity ratio, unlike that of any individual firm where arbitrage governed, would reflect the risk preferences of households for holding wealth, including, needless to say, those preferences arising from life-cycle considerations. A general equilibrium macroeconomic model of the determination of aggregate real investment and the aggregate debt/equity ratio did appear as an appendix to the original working paper version of the article. But we found problems with one of the equations and removed the appendix from the version submitted for publication, intending to "get back to it someday." That day, alas, has yet to come, but some of the flavor at least of that general equilibrium treatment reappears in several later articles, notably Miller (1977), Miller and Scholes (1978), and Modigliani (1982). 


\section{Arbitrage, Dividends and the Corporate Veil}

The law of one price is easily visualized in commodity settings where market institutions deliberately provide the necessary standardization and interchangeability of units. But to which of the many features of an entity as complex as an operating business firm would our financial equilibration extend?

We opted for a Fisherian rather than the standard Marshallian representation of the firm. Irving Fisher's view of the firm - now the standard one in finance, but then just becoming known-impounds the details of technology, production, and sales in a black box and focuses on the underlying net cash flow. The firm for Fisher was just an abstract engine transforming current consumable resources, obtained by issuing securities, into future consumable resources payable to the owners of the securities. Even so, what did it mean to speak of firms or cash flow streams being different, but still "similar" enough to allow for arbitrage or anything close to it?

Some of the answers would be provided, we hoped, by our concept of a "risk class," which was offered with several objectives in mind. At the level of the theory, it defined what today would be called a "spanning" set; the uncertain, underlying future cash flow streams of the individual firms within each class could be assumed perfectly correlated, and hence perfect substitutes. But the characteristics of those correlated streams could be allowed to differ from class to class. Hence, at the more practical level, the risk class could be identified with Marshallian industries-groupings around which so much academic and Wall Street research had always been organized. (Remember, in this connection, that the capital asset pricing models of Sharpe (1964) and Lintner (1965) and their later extensions that now dominate empirical research in finance had yet to come on the scene. For some glimpses of how more recent asset pricing frameworks can accommodate the MM propositions without reference to MM risk or MM arbitrage, see the comment by Stephen Ross that follows this article.) We hoped that the earnings of firms in some large industries such as oil or electricity generation might vary together closely enough not just for real world arbitragers to carry on their work of equilibration efficiently, but also to offer us as outside observers a chance of judging how well they were succeeding. Indeed, we devoted more than a third of the original paper (plus a couple of follow-up studies, notably Miller and Modigliani, 1966) to empirical estimates of how closely real world market values approached those predicted by our model. Our hopes of settling the empirical issues by that route, however, have largely been disappointed. Direct statistical calibration of the goodness of fit of the MM value-invariance propositions has not so far been achieved by us or others for a variety of reasons, some of which will be noted further in due course below.

\section{Investor Arbitrage When Dividends Differ: The Dividend Invariance Proposition}

Although the risk class, with its perfect correlation of the underlying real cash streams, may have provided a basis for the arbitrage in our formal proof, there remained the sticking point of how real world market equilibrators could gain access to a firm's operating cash flows, let alone to two or more correlated ones. As a matter 
of law, what the individual equity investor actually gets on buying a share is not a right to the firm's underlying cash flow, but only to such cash dividends as the corporation's directors choose to declare. Must these man-made payouts policies also be assumed perfectly correlated along with the underlying cash flows to make the equilibration effective? If so, the likely empirical range of the value-invariance proposition would seem to be narrow indeed.

A second MM invariance proposition - that the value of the firm was independent of its dividend policy-was developed in part precisely to meet this class of objections. The essential content of the dividend irrelevance argument was already in hand at the time of the original leverage paper and led us there to dismiss the whole dividend question as a "mere detail" - not the last time, alas, that we may have overworked that innocent word "mere." We stated the dividend invariance proposition explicitly, and noted its relation to the leverage proof in the very first round of replies to our critics (Modigliani and Miller, 1959, esp. pp. 662-668). But because dividend decisions were controversial in their own right and because considering them raised so many side issues of valuation theory and of practical policy, both private and public, we put off the fuller treatment of dividends to a separate paper that this time really did appear, but only in 1961, some three years after the first one.

That the close connection in origin of the two invariance propositions has not been more widely appreciated traces not only to their separation in time, but probably also to our making no reference to arbitrage (or even to debt or equity) in the proof of the dividend invariance proposition. Why bring in arbitrage, we felt, when an even simpler line of proof would serve? The dividend invariance proposition stated only that given the firm's investment decision, its dividend decision would have no effect on the value of the shares. The added cash to fund the higher dividend payout must come from somewhere, after all; and with investment given, that somewhere could only be from selling off part of the firm. As long as the securities sold off could be presumed sold at their market-determined values, then, whether the analysis was carried out under conditions of certainty or uncertainty, the whole operation of paying dividends, investment given, could be seen as just a wash - a swap of equal values not much different in principle from withdrawing money from a passbook savings account.

The informational content of dividends. Managerial decisions on dividends thus might affect the cash component of an investor's return; but they would not affect the total return of cash plus appreciation, and the total is what mattered. In practice, of course, even changing the cash-dividend component often seemed to matter a great deal, at least, to judge by the conspicuous price jumps typically accompanying announcements of major boosts or cuts in dividends. These highly visible price reactions to dividend announcements were among the first (and are still the most frequently mentioned) of the supposed empirical refutations of the MM value-invariance principle. By invoking the dividend invariance proposition to support the leverage invariance proposition, we seemed to have succeeded only in substituting one set of objections for another. 
But, as we suggested in the 1961 dividend paper, these price reactions to dividend announcements were not really refutations. They were better seen as failures of one of the key assumptions of both the leverage and dividend models, namely, that all capital market participants, inside managers and outside investors alike, have the same information about the firm's cash flows. Over long enough time horizons, that all-cards-on-the-table assumption might, we noted, be an entirely acceptable approximation, particularly in a market subject to Securities and Exchange Commission disclosure rules. But new information is always coming in; and over shorter runs, the firm's inside managers were likely to have information about the firm's prospects not yet known to or fully appreciated by the investing public at large. Managementinitiated actions on dividends or other financial transactions might then serve, by implication, to convey to the outside market information not yet incorporated in the price of the firm's securities.

Although our concern in the 1961 dividend paper was with the observed announcement effects of dividend decisions, informational asymmetry also raised the possibility of strategic behavior on the part of the existing stockholders and/or their management agents. Might not much of the price response to dividend (and/or other capital-structure) announcements simply be attempts of the insiders to mislead the outsiders; and if so, what point was there to our notion of a capital market equilibrium rooted solely in the fundamentals? Our instincts as economists led us to discount the possibility that firms could hope to fool the investing public systematically; but at the time, we could offer little more support than a declaration of faith in Lincoln's Law - that you can't fool all of the people all of the time. By the 1970s, however, the concept of an information equilibrium had entered economics, and it soon came to the field of corporate finance as well. Bhattacharya (1979) noted the formal similarity between Spence's (1973) job-market signalling model and the MM dividend model with asymmetric information. Ross (1977) showed how debt/equity ratios might also serve to signal, in the technical sense, managements' special information about the firm's future prospects. The extent to which these and subsequent asymmetric information models can account for observed departures from MM invariance has not so far been convincingly established, however. ${ }^{3}$

The interaction of investment policy and dividend policy. The dividend invariance proposition, as we initially stated it, highlights still another way in which the corporate form of organization, and especially the separation it permits between ownership and management, can have effects that at first sight at least seem to contradict the MM value-invariance predictions. Recall that the dividend invariance proposition takes the firm's investment decision as given, which is just a strong way of saying that the level of investment, whatever it might be, is set by management independently of the dividend. Without imposing such an "other-things-equal" condition, there would, of

\footnotetext{
${ }^{3}$ For a survey of recent results on dividend signalling see Miller (1987). For a survey of asymmetric information models in finance more generally see Stiglitz (1982).
} 
course, be no way of separating the market's reaction to real investment events from reaction to the dividend and any associated purely financial events.

In the real world, of course, the financial press reports single-company stories, not cross-sectional partial regression coefficients. In these single-company tales, the investment decision and the dividend/financing decisions are typically thoroughly intertwined. But if the tale is actually one of a firm cutting back unprofitable investments and paying out the proceeds as dividends, followed by a big run-up in the firm's price, then the MM invariance proposition may seem to be failing, but it is really not being put to the test. Nor is this scenario only hypothetical. Something very much like it appears in a number of the most notorious of recent takeover battles, particularly in the oil industry where some target firms had conspicuously failed to cut back their long-standing policies of investment in exploration despite the drastic fall in petroleum prices.

In a sense, as noted earlier, these gains to shareholders from ending a management-caused undervaluation of the firm's true earning power can also be viewed as a form of capital market arbitrage, but not one that atomistic $\mathrm{MM}$ investors or arbitragers can supply on their own. Once again, the special properties of the corporate form intrude; this time the issue is the voting rights that attach to corporate shares and the majority rules (and sometimes supermajority rules) in the corporate charters that determine the control over the firm's decisions. Much of the early skepticism, still not entirely dispelled, about the real empirical force of interfirm arbitrage, MM-arbitrage included, traces to these properties of corporate shares beyond their purely cash-flow consequences. A particular example of the obstacle they offered to effective capital market equilibration was that of closed-end investment funds. In 1958, as still today, closed-end funds often sold in the market at a substantial discount to net asset value- a discount the could be recaptured by the shareholders merely (that word, again!) by getting enough of them to vote to convert to open-end fund status.

Voting rights were one, but only one, of the special properties of corporate common shares from which the MM model abstracted. There was another, namely limited liability, which appeared to loom even larger as an obstacle to the "homemade" leverage on which the arbitrage proof relied. That was the second of the early lines of objection to the invariance proposition and its proof. As is turns out, limited liability is not really critical either to the proof or to the empirical force of the invariance proposition. But it may have been made to seem so at the time by an unfortunate tactical simplification we made in presenting the original proof.

\section{Invariance with Limited Liability and Risky Debt}

The troublesome tactical simplification in the original proof was our taking bonds or other debt instruments to be securities not merely of lower risk than common stocks, but of no risk whatever. The promises their issuers made would be honored. Drawing so sharp a line between risky stocks and riskless bonds served, we thought, to bring out 
the risks of corporate leveraging as such, and, to that extent, also to explain how the seeming gains from using cheap debt can be offset by the higher risks and hence costs of leveraged equity (our MM Proposition II) keeping the weighted average risks and costs the same (our Proposition I). But making bonds riskless also made all debts effectively indistinguishable, thereby, leaving corporate finance, in the strict sense, with nothing to do. Individual investors, creating or eliminating leverage with debts on their personal accounts, could always match or undo any capital structure decision at the corporate level. Thus, ironically, the riskless debt assumption we introduced orirginally to sharpen the line between corporate stocks and bonds seemed to have blurred the line between the corporation and other forms of business organization.

\section{Arbitrage When Corporations, But Not Individual Investors, Have Limited Liability}

Limiting the liability for the firm's debts to the initial capital contribution was, after all, one of the presumed advantages that had led the owner-organizers of capital-intensive enterprises to substitute the corporate form for personal proprietorships or partnerships in which their own personal wealth would have been open to unsatisfied creditors. Hence individuals could not really hope to duplicate corporate structures on their own as the original $\mathrm{MM}$ arbitrage proof seemed to require, unless - to avoid any chance of default - further and unrealistically severe restrictions were imposed both on the firm's worst-outcome cash flow prospects and on the amounts of debt it could issue.

In defense of our simplification let it be noted at least that the notion of an idealized riskless rate of interest had long been, and still remains, in the standard tool-kit of economic theory. We also had no qualms about gaps that our riskless debt restriction might open in the spectrum of risks available to investors. Even if our firms did not fill the zone between riskless debts and risky equities with low, but more-thanriskless-instruments, investors could always span it by mixing stocks with riskless bonds in their personal portfolios.

There was, moreover, one sense, though a limited one, in which both the value-invariance proposition and the arbitrage proof would go through even though shareholders in levered corporations, but not individuals levered on private account, had limited liability in the event of a default. That institutional difference in liability need not be critical so long as the potential arbitragers in the household sector were substantial net creditors to the corporate sector. They could then bring about the equivalent of any required increase in limited-liability leveraging of unlevered shares merely by selling off some of the risky corporate bonds held in their personal portfolios. The same sort of argument could be invoked, as we noted, not just for risky corporate bonds but for other securities that are specific to corporate issuers, such as preferred stocks.

\section{Corporations as Arbitragers}

An even more effective way of finessing the limited-liability issue and, in the process, of emphasizing that the assumed risklessness of the debt was not the key to the invariance result or its arbitrage proof, would have been to permit corporations 
generally, and not just individuals, to participate in the equilibrating arbitrage operations. Such an extension of the set of eligible arbitragers (suggested, in fact, by some early commentators on our paper, notably Stiglitz $(1969,1974))$, may perhaps have escaped us at the time because of the mind set induced by our sectoral consolidation tableaus in which firms and households were assigned such fundamentally distinctive economic roles. Had we drawn those roles less sharply and let corporations hold securities as assets as well as issue them as liabilities (as in the models of Duffie and Shafer, 1986), we might have spared the profession much needless subsequent controversy. The real world, needless to say, has always been far less fastidious than we were in sharply differentiating the functions of firms and households; much of what passes these days for corporate-raiding-cum-restructuring is just MM leverage arbitrage, but channeled through the raider's corporate, rather than personal, investment account.

\section{Corporations and Financial Innovation}

With risky debt and active corporate players, the general equilibrium issue of invariance of real allocations to financial policies must also be reopened, because some prospect then arises for "creative" corporate finance. Through new, high leverage, limited-liability securities, firms might enhance their own value (and the social welfare) by offering risk and return combinations that fully-liable investors could not hope to achieve on their own.

Such new, high risk opportunities might well have been among the first sources to be looked to had the recent spectacular gains from corporate restructuring occurred in the late 1960s or early 1970s. High leverage was far from easy to come by in those days. And even today, the scarcity of long-term ultra-high leverage opportunities may perhaps account for some of the otherwise perplexingly high prices for the shares-or "stubs" as they are sometimes disparingly called-left over after some recent massive debt-financed corporate share repurchases. But it is hard to see any major role in the gains from recent restructurings by U.S. industrial corporations that can be traced to the creation of limited liability, high-risk investment opportunities by ordinary corporations in a form not otherwise attainable by individual investors. That some gains have arisen from "expanding the state space" with new kinds of financial instruments and financial repackagings may well be true, of course. An example of such marketcompleting repackagings might be Collateralized Mortgage Obligations, where the uncertain, interest-rate-driven repayments of the underlying household mortgages may have created a new kind of interest rate risks, and hence of interest rate hedges, not found in the normal run of debt instruments. (Some cynics might be more inclined to credit any gains from CMO's to opening holes in the regulatory net covering the savings and loan sector.) But with few exceptions (among them, perhaps, so-called auction-rate preferred stocks and some recent securities linked to commodities and exchange rates) the panoply of corporate securities is pretty much what it always has been. The main financial innovations of recent years have come not from operating corporations, but from the commodity and securities exchanges which have created an entirely new noncorporate family of limited-liability instruments for investors. With 
these instruments has also come a new way of looking at corporate capital structures and the MM propositions.

\section{The Options Interpretation of Levered Stock}

The new instruments offering individual investors low cost, limited-liability substitutes for corporate leverage were, of course, put and call options and their many variations and permutations. The mechanics of option theory are by now too well-known among economists to warrant extensive review here, but the insights the existence of options gives to the economic (as opposed to the legal) view of debt, and especially risky debt, are perhaps still worth a further word or two. ${ }^{4}$

The legal view of debt, reflected also in the everyday usage of the term, involves a long laundry list of attributes whose essence is obligation. Debts are promises by the debtor to pay specific amounts on specific dates. If the promise is not kept, the creditor can sue.

The restrictiveness of any definition of debt relying mainly on the notions of obligation and legal remedies becomes clear immediately on confronting the complexities of real world capital structures. Where, to name just one of a hundred forms of fancy-featured corporate securities, is something even as simple and familiar as preferred stock to be placed? For the common stockholders, the fixed-maximum dividend on preferred shares clearly provides leverage in exactly the same way as would a fixed-interest bond. Yet in law (including tax law) and in accounting, preferred stock is an equity security since it carries no enforceable obligation to pay. The discretion to pay preferred dividends is normally left entirely to the corporation's directors, as it is with dividends on common. The directors will choose to pay the preferred dividends only if the costs to common shareholders of not paying themmainly delay (possibly long) of cash dividends on the common, possibly some reduction in voting power and certainly some loss of reputation capital for future financings-exceed those of honoring the promise. But that is true as much for securities that are legal debts as it is for preferred shares. The firm pays its debts not just because the law says it must, but because the value of the stock to its shareholders is greater to them if the firm pays the debts than if it doesn't. Otherwise the shareholders can default on the payment, invoke limited liability and turn the keys over to the bondholders.

The shareholders in a levered, limited-liability corporation are thus essentially the owners of a call option whose exercise price is the promise in the senior securities. The academic finance profession is still exploring the full ramifications of this important insight, which traces along with so much else to the original Black-Scholes option paper (1973). That it has already thrown new light on the MM propositions is hardly surprising since MM-type arbitrage arguments were explicitly invoked by Black and Scholes in deriving their option valuation formula. A key to their derivation was their recognition that a stock and an option on that stock were in the same "risk class" (that

\footnotetext{
${ }^{4}$ An interpretive review of the basics of option theory is given by Rubenstein (1987) in an earlier issue of this journal.
} 
is, they were prefectly correlated) at least for local variations in their prices; and that they could be kept in the same risk class in the face of larger price variations by dynamic rebalancing of the number of options over time.

The put-call parity theorem as an MM proposition. The closeness of the connection between modern option theory and the earlier MM analysis stands out even more strikingly when attention turns to the relations between the prices of different options on the same stock. The familiar Put-Call Parity Theorem (first stated formally in Stoll, 1969), is really nothing more than the MM Proposition I in only a mildly concealing disguise!

To see this, recall the put-call parity requires that, under frictionless conditions, the following relation must hold as an equality for any value of $K$ :

$$
S=C(K)+K e^{-r t}-P(K)
$$

where $S$ is the current price of the stock against which the put and call options are to be written, $K$ the common exercise price of the options, $T$ the time to maturity of the options, $r$ the riskless rate of interest, and $C(K)$ and $P(K)$ the current prices of the call and put options respectively. Now reinterpret each term in the light of the Black-Scholes capital structure analogy. (For simplicity, pretend that the firm has outstanding only a single, zero coupon bond. More general cases are considered in Merton (1974) and Black and Cox (1976).) $S$ becomes the value of the firm's cash flow; $K$ the face or book value of the firm's liabilities; and $C(K)$ the market value of the levered shares in the firm. $K e^{-r T}$ is the market value that the firm's debt would have if it were riskless. But of course, it is not riskless. Should the value of $S$ at maturity of the debt turn out to be less than $K$, the shareholders will invoke limited liability and put the firm back to the creditors. The actual market value of the debt is thus only $K e^{-r T}-P(K)$, the present face value of the debt less the value of the shareholders' put. The market value both of the firm's debts and its equity are thus clearly functions of the firm's leverage. But by the Put-Call Parity Theorem as shown in the equation, their sum is independent of leverage. The combined pieces of the capital structure always add up to $S$, the value of the underlying unlevered cash flow exactly as in the MM Proposition I.

Not the least of the gains from invoking the Put-Call Parity analogy is the light it throws on the problems of establishing empirically the goodness of fit of the MM Propositions. The fit of Put-Call Parity can be calibrated because all its terms are directly observable. But the "true" value of a firm-the MM concept that corresponds to the $S$ in the equation describing of the Put-Call Parity Theorem-or the "risk class" to which the firm belongs, is not observable.

Even without formal statistical testing, however, we have no shortage of potential candidates for forces that might well lead the market to depart systematically and persistently from the predictions of the original MM value-invariance propositions. One such likely candidate, the third of the original lines of objection, has loomed so large in fact as to have dominated academic discussions of the MM propositions, at least until the recent wave of corporate takeovers and restructurings became the new 
focus of attention. That candidate is the corporate income tax, the one respect in which everyone agreed that the corporate form really did matter.

\section{The MM Propositions in a World with Taxes}

The U.S. Internal Revenue Code has long been the classic, and by now is virtually the world's only, completely unintegrated tax system imposing "double taxation" of corporate net income. A separate income tax is first levied directly in the corporation and, except for certain closely-held corporations who may elect to be taxed like partnerships under Subchapter $\mathrm{S}$ of the Code, a second tax is then levied at the personal level on any income flows such as dividends or interest generated at the corporate level. Double taxation of the interest payments is avoided because interest on indebtedness is considered a cost of doing business and hence may be deducted from corporate gross income in computing net taxable corporate earnings. But no such allowance has been made for any costs of equity capital. ${ }^{5}$

If the separate corporate income tax were merely a modest franchise tax for the privilege of doing business in corporate form, as was essentially the case when it was introduced in the early years of this century, the extra burden on equity capital might be treated as just one more on the long list of second-order differences in the costs of alternative sources of capital for the firm. But at the time of our 1958 article the marginal tax rate under the corporate income tax had been close to and sometimes over 50 percent for nearly 20 years and it remained there for almost another 30 years until dropped to 34 percent by the Tax Reform Act of 1986. Cost differentials of this size were just too big to be set aside in any normative or empirical treatments of real world capital structure choices.

Strictly speaking, of course, there is one sense, albeit a somewhat strained one, in which the basic value-invariance does go through even with corporate taxes. The Internal Revenue Service can be considered as just another security holder, whose claim is essentially an equity one in the normal course of events (but which can also take on some of the characteristics of secured debt when things go badly and back taxes are owed). Securities, after all, are just ways of partitioning the firm's earnings; the MM propositions assert only that the sum of the values of all the claims is independent of the number and the shapes of the separate partitions.

However satisfying this government-as-a-shareholder view may be as a generalization of the original model, the fact remains that the government, though it sometimes gives negative taxes or subsidies for some kinds of investment, does not normally buy its share with an initial input of funds that can serve to compensate the other stockholders for the claims on income they transfer to the Treasury. Nor are we talking here of taxation-according-to-the-benefits or of the rights of eminent domain,

\footnotetext{
${ }^{5}$ Two exceptions should be noted for the record. An undistributed profits tax from which dividends were deductible was in force for two years in the late 1930s. The excess profits tax during World War II also allowed a deduction not for dividends, but for the "normal profits" of the firm.
} 
or even of whether the corporate tax might ultimately be better for the shareholders or for the general public than alternative ways of raising the same revenue. For the nongovernment equity claimholders, the government's claim to the firm's earnings is a net subtraction from their own.

\section{The MM Tax-adjusted Leverage Proposition}

Allowing for that subtraction can lead to a very different kind of MM Proposition, though one, as we showed in our Tax Correction article (1963) that can still be derived from an arbitrage proof along lines very similar to the original. This time, however, the value of the firm (in the sense of the sum of the values of the private, nongovernmental claims) is not independent of the debt/equity division in the capital structure. In general, thanks to the deductibility of interest, the purely private claims will increase in value as the debt ratio increases. In fact, under conditions which can by no means be dismissed out of hand as implausible, we showed that the value of the private claims might well have no well-defined interior maximum. The optimal capital structure might be all debt!

In many ways this tax-adjusted MM proposition provoked even more controversy than the original invariance one, which could be, and often was, shrugged off as merely another inconsequential paradox from some economists' frictionless dreamworld. But this one carried direct and not very flattering implications for the top managements of companies with low levels of debt. It suggested that the high bond ratings of such companies, in which the management took so much pride, may actually have been a sign of their incompetence; that the managers were leaving too much of their stockholders' money on the table in the form of unnecessary corporate income tax payments, payments which in the aggregate over the sector of large, publicly held corporations clearly came to many billions of dollars.

We must admit that we too were somewhat taken aback when we first saw this conclusion emerging from our analysis. The earlier modeling of the tax effect in our 1958 paper, which the 1963 paper corrected, had also suggested tax advantages in debt financing, but of a smaller and more credible size. By 1963, however, with corporate debt ratios in the late 1950s not much higher than in the low tax 1920s (see Miller, 1963) we seemed to face an unhappy dilemma: either corporate managers did not know (or perhaps care) that they were paying too much in taxes; or something major was being left out of the model. Either they were wrong or we were.

The offsetting costs of debt finance. Much of the research effort in finance over the next 25 years has been spent, in effect, in settling which it was. Since economists, ourselves included, were somewhat leerier then than some might be now in offering mass ineptitude by U.S. corporate management as an explanation for any important and long-persisting anomalies, attention was naturally directed first to the possibly offsetting costs of leveraging out from under the corporate income tax. Clearly, leveraging increased the riskiness of the shares, as we ourselves had stressed in our original Proposition II and its tax-adjusted counterpart. A sequence of bad years, moreover, might wipe out the firm's taxable income, and, given the very ungenerous treatment of losses in our tax law, that could reduce, possibly quite substantially, any 
benefits from the interest tax shields. A run of very bad years might actually find a highly-levered firm unable (or, as the option theorists might prefer, unwilling) to meet its debt service requirements, precipitating thereby any of the several processes of recontracting that go under the general name of bankruptcy. These renegotiations can be costly indeed to the debtor's estate, particularly when many separate classes of creditors are involved. ${ }^{6}$

The terminal events of bankruptcy are not the only hazards in a high debt strategy. Because the interests of the creditors and the stockholders in the way the assets are managed need not always be congruent, the creditors may seek the additional protection of restrictive covenants in their loan agreement. These covenants may not only be costly to monitor but may foreclose, if only by the time delay in renegotiating the original terms, the implementation of valuable initiatives that might have been seized by a firm less constrained. Nor should the transaction and flotation costs of outside equity financing be neglected, particularly in the face of information asymmetries. Prudence alone might thus have seemed to dictate the maintenance of a substantial untapped reserve of quick borrowing power, especially in an era when those managing U.S. corporations (and the financial institutions buying their debt securities) still had personal memories of the debt refinancing problems in the 1930s.

We dutifully acknowledged these well-known costs of debt finance, but we were hard put at the time to see how they could overweigh the tax savings of up to 50 cents per dollar of debt that our model implied. Not only did there seem to be potentially large amounts of corporate taxes to be saved by converting equity capital to deductible-interest debt capital, but there appeared to be ways of doing so that avoided, or at least drastically reduced, the secondary costs of high-debt capital structures. The bankruptcy risk exposure of junior debt could have been blunted with existing hybrid securities such as income bonds, to take just one example, under which deductible interest payments could be made in the good years, but passed or deferred in the bad years without precipitating a technical default. For reducing the moral hazards and agency costs in the bondholder-stockholder relation, the undoing-of-leverage blade in the original MM proof offered a clue: let the capital suppliers hold some of each, either directly or through convertible or exchangeable securities of any of a number of kinds. In sum, many finance specialists, myself included, remained unconvinced that the high-leverage route to corporate tax savings was either technically unfeasible or prohibitively expensive in terms of expected bankruptcy or agency costs.

\section{Junk Bonds, Leveraged Buyouts, and the Feasibility of High Leverage Strategies}

A number of recent developments in finance can be seen as confirming the suspicions of many of us academics in the early 1960s that high leverage strategies to reduce taxes were indeed entirely feasible. Among these, of course, is the now large outstanding volume of what are popularly known as "junk bonds." The very term is a

\footnotetext{
${ }^{6}$ The perceived complexity of the present bankruptcy code (and perhaps even the very reason for having such a code) reflect mainly the need for resolving conflicts within and between the various classes of creditors. The difficulties parallel those encountered elsewhere in "common pool" problems (Jackson, 1986).
} 
relic of an earlier era in which the distinguishing characteristic of bonds as investments was supposedly their presence at the low-risk end of the spectrum. High-risk, high-yield bonds did exist, of course, but were typically bonds issued initially with high ratings by companies that had subsequently fallen on hard times. The significant innovation in recent years - and it is still a puzzle as to why it took so long-has been in the showing that, contrary to the conventional wisdom, junk bonds could in fact be issued and marketed successfully by design, and not just as "fallen angels."

The designs utilizing new risky-debt securities have often taken the very conspicuous form of "leveraged buyouts" of the outside shareholders by a control group typically led by the existing top management. The device itself is an old one, but had been confined mainly to small firms seeking both to assure their continuity after the death or retirement of the dominant owner-founder, and to provide more liquidity for the entrepreneur's estate. The new development of recent years has been the ability, thanks in part to the market for junk bonds, to apply the technique to a much wider range of publicly held big businesses with capitalizations now routinely in the billions, and with new size records being set almost every year.

The debt/equity ratios in some recent LBO's have reached as high as 9 to 1 or 10 to 1 or even more, far beyond anything we had over dared use in our numerical illustrations of how leverage could be used to reduce taxes. The debtor/creditor incentive and agency problems that might be expected under such high leverage ratios have been kept manageable partly by immediate asset sales, but over the longer term by "strip financing" - trendy investment-banker argot for the old device of giving the control and most of the ownership of the equity (except for the management incentive shares) to those providing the risky debt (or to the investment bankers they have designated as monitors). The same hold-both-securities approach, as in our arbitrage proof, has long been the standard one in Japan where corporate debt ratios are, or are at least widely believed to be, substantially higher than for their U.S. counterparts.

Some possible non-tax gains from leveraging. The recent surge of leveraged buyouts not only shows the feasibility of high leverage capital structures for reducing corporate income taxes, but also suggests at least two other possible sources for the gains to the shareholder that may accompany a major recapitalization with newly-issued debt. The firm may, for example, already have had some long-term debt outstanding when the additional debt needed to accomplish the buyout was arranged. Even in a no-tax world the "no gain from leverage" implication of the original MM invariance proposition might fail if the new debt was not made junior in status to the old, if the old bond covenant was "open ended," as many still are, and if the new bonds were issued under it. Assuming no change in the underlying earning power from the recapitalization, the original creditors would then find the value of their claim diluted. The benefits of this dilution of the old bondholders accrue, of course, to the stockholders, which is why it has often been labeled "theft," particularly by the adversely affected bondholders. Finance specialists prefer the less emotionally charged term "uncompensated wealth transfer."

The high debt ratios in LBO's also redirect attention to the assumption, shown earlier to be crucial to the MM dividend invariance proposition, that the firm's 
financial decisions can be taken as independent of its real operating and investment decisions. That assumption never sits well and certainly the notion that heavy debt burdens might indeed lead to overcautious business behavior has long been part of the folk wisdom on the dangers of debt. The new wrinkle to the interdependence argument brought in recently by the defenders of LBO's has been to stress the positive virtues of having managers face large debt obligations. Managements in such firms must work hard and diligently indeed to achieve any earnings above interest to enhance the value of the residual equity they hold in the firm. By accepting such heavy debt-service burdens, moreover, the managers are making a binding commitment to themselves and to the other residual equity holders against yielding to the temptations, noted earlier, to pour the firm's good money down investment rat holes. ${ }^{7}$

Voluntary recapitalizations and the $\mathrm{MM}$ dividend proposition. High debt ratios have been installed in some U.S. firms in recent years not just by outside-initiated LBO's but through voluntary recapitalizations. Sometimes, it is true, the motivation has been merely to fend off an imminent hostile takeover, but sometimes the tax benefits have been very clearly emphasized. Even apart from the tax angles, nothing in the practice of finance these days could be more quintessentially MM than these often highly visible "self takeovers," as some wag has dubbed them. Leverage-increasing recapitalizations of this kind do indeed raise the firm's debt/equity ratio, but because the proceeds of the new bonds floated are turned over to the shareholders, the self takeovers also reunite in a single operation the two Siamese-twin MM propositions, the leverage proposition and the dividend proposition, joined together originally at birth, but soon parted and living separate lives thereafter.

The dividend proposition, as noted earlier, was put forward initially to overcome a line of objection to the leverage proof. But how dividends might actually affect real world prices raises other issues, which in turn have led to as much controversy and to an even larger number of discordant empirical findings. Once again, moreover, major tax differentials intruded, this time the gap between rates on dividends and capital gains under the personal income tax, again with what seemed in the late 1950s and early 1960 s to have strikingly unorthodox policy implications. Some high income stockholders clearly would have been better off if the firm paid no dividends and simply reinvested its earnings or bought shares in other corporations. That much every real-world conglomerator and every public finance specialist surely knew. But the value-for-value presumption of the MM dividend proposition carried within it some further advice. There were better ways to avoid taxes on dividends than pouring the firm's money down rat holes; for one, use the money to buy back the firm's shares! For the taxable shareholders, buybacks at market-determined prices could transform heavily-taxed dividends into less-heavily taxed capital gains, and, better yet, into unrealized capital gains for shareholders who choose not to sell or trade their shares. Unlike a declared regular dividend, moreover, an announced share repurchase,

\footnotetext{
${ }^{7}$ This view of debt service as a device for reining in managerial discretion is a major strand in what has come to be called the "free cash-flow" theory of corporate finance. For an account of that theory in an earlier issue of this journal, see Jensen (1988).
} 
whether by tender or by open market purchases, carried no implied commitments about future payouts.

\section{Personal-corporate Tax Interactions and Capital Market Equilibrium}

These tax-advantaged dividend-substitution properties of share repurchase may also offer a clue as to why the leveraging of corporate America out from under the corporate income tax may have been so long delayed. The point is not so much that share repurchase by itself has been a major vehicle deliberately invoked by corporations to reduce the personal income taxes of their shareholders, though its potential for that purpose certainly has not been lost on corporate treasurers and directors. ${ }^{8}$ But the very presence of such a possibility at the corporate level serves as a reminder that the U.S. tax system has not one but two distinct taxes that bear on capital structure choices. Any model of capital market equilibrium must allow for both, and for their interactions.

In particular, under reasonable assumptions, the joint corporate-personal tax gains from corporate leverage, $G_{L}$ can be expressed in the following relatively transparent formula (see Miller, 1977):

$$
G_{L}=\left[1-\frac{\left(1-t_{c}\right)\left(1-t_{P S}\right)}{1-t_{P B}}\right] B_{L}
$$

where $B_{L}$ is the value of the levered firm's interest-deductible debts, $t_{c}$ is the marginal corporate tax rate and $t_{P S}$ and $t_{P B}$ are the marginal investor's personal marginal tax rates respectively on income from corporate shares and income from interest-bearing corporate debts. In the special case in which the personal income tax makes no distinction between income from debt or from equity (that is, $t_{P S}=t_{P B}$ ), the gain from leverage reduces to $t_{c} B_{L}$, precisely the expression in the MM tax model. ${ }^{9}$ But in the contrasting extreme special case in which (a) the capital gains provisions or other special reliefs have effectively eliminated the personal tax on equity income, (b) full loss offsets are available at the corporate level and (c) the marginal personal tax rate on interest income just equals the marginal corporate rate, the purely tax gains from corporate leverage would vanish entirely. The gains from interest deductibility at the corporate level would be exactly offset by the added burden of interest includability under the personal tax - an added burden that in equilibrium would be approximated by risk-adjusted interest rate premiums on corporate and Treasury bonds over those on tax-exempt municipal securities.

\footnotetext{
${ }^{8}$ Most economists, upon first hearing about share repurchase as an alternative to dividend payments, assume that the Internal Revenue Service must surely have some kind of magic bullet for deterring so obvious a method of tax avoidance. (See Bhattacharya, this issue.) It doesn't; or at least not one that will work in the presence of even minimally competent tax lawyers.

${ }^{9}$ That special case assumes, among other things, that debt, once in place, is maintained or rolled over indefinitely. For valuing the tax savings when debts are not perpetuities, see the comment on this paper by Franco Modigliani in this issue.
} 
This somewhat surprising special case of zero net gain from corporate leverage has inevitably received the most attention, but it remains, of course, only one of the many potentially interesting configurations for market equilibrium. Stable intermediate cases are entirely possible in which some gains to corporate leverage still remain, but thanks to the capital gains or other special provisions driving $t_{P S}$ below $t_{P B}$, or to limitations on loss offsets, those gains at the corporate level are substantially below those in the original MM tax model. The tax gains from leverage might, in fact, even be small enough, when joined with reasonable presumed costs of leverage, to resolve the seeming MM anomaly of gross underleveraging by U.S. corporations. For some recent empirical tests of such an intermediate equilibrium using the premium over municipals, see Buser and Hess (1986). Kim (1987) offers a wide-ranging survey of recent theoretical and empirical research on capital market equilibrium in the presence of corporate-personal income tax interactions.

\section{The MM Propositions and the Recent Tax Reform Act}

Any such "Debt and Taxes" equilibrium, however, that the corporate sector might have reached in the early 1980s by balancing costs of debt finance against MM tax gains from leverage must surely have been shattered by the Tax Reform Act of 1986. That act sought (among other things) to reverse the long steady slide, accelerating in the early 1980s, in the contribution of corporate income taxes to total federal tax revenues. But in attempting to increase the load on corporations, Congress seemed to have overlooked some of the interactions between corporations and individual investors that lie at the heart of the MM propositions and their later derivatives. For shareholders taxable at high marginal rates on interest or dividends under the personal income tax, for example, maintaining assets in corporate mode and suffering the corporate tax hit might make sense, provided enough of the after-corporate-tax earnings could be transmuted to long-deferred, low-taxed capital gains by profitable reinvestment in real assets. In fact, over much of the life of the income tax, when shares were held largely by wealthy individuals and hardly at all by pension funds or other tax-exempt holders, the corporate form of organization for business with great growth potential may well have been the single, most important tax shelter of all.

But the pattern of tax advantages that encouraged the encouraged the accumulation of wealth in corporate form appears to have been altered fundamentally by the Tax Reform Act of 1986. The investment tax credit and related tax subsidies to fixed investment have been phased out. The marginal rate on the highest incomes under the personal income tax has now been driven to 28 percent and hence below the top corporate rate of 34 percent. The long-standing personal income tax differential in favor of long-term realized capital gains has been eliminated, though income in that form still benefits from a variety of timing options and from the tax-free write-up of any accumulated gains when the property passes to heirs. The analogous tax-free write-up privileges for corporate deaths or liquidations, however, formerly allowed under the so-called General Utilities doctrine, have now been cut back by the TRA and some of its recent predecessors, reducing still further the tax benefits of the corporate form. 
To finance specialists familiar with the MM propositions, these combined changes suggest that Congressional hopes of substantially increasing the yield of the corporate income-tax - that is to say, their hopes of reinstating the double taxation of corporate profits-may well be disappointed. (For some recent signs of congressional concerns on this score see Brooks (1987) and Canellos (1987).) Our capital markets and legal institutions offer too many ways for averting the double hit. Corporations can split off their cash-cow properties into non-corporate "flow-through" entities. And, as has been the running theme of this entire section, firms retaining corporate form can always gut the corporate tax with high leverage capital structures. In fact, under not entirely implausible conditions (notably that the marginal bondholder is actually a tax-exempt pension fund rather than a taxable individual investor, implying that the $t_{P B}$ in the gains from leverage equation is zero), the incentive to leverage out the corporate tax may now actually be as high or higher than it was back in 1963. The statutory top corporate tax rate has indeed been cut; but with the investment tax credit and accelerated depreciation also blown away by the Tax Reform Act of 1986, many capital-intensive corporations may now, for the first time in a very long while, be facing the unpleasant prospect of actually paying substantial corporate taxes.

Perhaps that observation can serve as a fitting note of uncertainty, or at least of unfinished business on which to close this look back at the MM propositions. The open questions about those propositions have long been the empirical ones, as noted here at many points. Are the equilibria implied by the propositions really strong enough attractors to demand the attention of those active in the capital markets either as practioners or as outside observers? In the physical or biological sciences one can often hope to answer such questions by deliberately shocking the system and studying its response. In economics, of course, direct intervention of that kind is rarely possible but nature, or at least Congress, can sometimes provide a substitute. The U.S. tax system is a pervasive force on business decisions of many kinds, but especially so on the class of financial decisions treated in the MM propositions. Tax considerations have for that reason always figured prominently in the field of finance. Occasionally, the profession may even see changes in the tax regime drastic enough for the path of return to a new equilibrium to stand out sharply against the background of market noise. Whether the Tax Reform Act of 1986 is indeed one of those rare supershocks that can validate a theory remains to be seen.

- Helpful comments on an earlier draft were made by George Constantinides, Melvin Reder, Lester Telser, Hal Varian, Robert Vishny and by the editors, Carl Shapiro, Joseph Stiglitz and Timothy Taylor. 


\section{References}

Bhattacharya, Sudipto, "Imperfect Information, Dividend Policy and the 'Bird in the Hand' Fallacy," Bell Journal of Economics, Spring 1979, 10, 1, 259-70.

Black, Fischer, and John Cox, "Valuing Corporate Securities: Some Effects of Bond Indenture Provisions." Joumal of Finance, May 1976, 31, 2, 351-67.

Black, Fischer, and Myron Scholes, "The Pricing of Options and Corporate Liabilities," Journal of Political Economy, May-June 1973, 83, 3, 637-54.

Brooks, Jennifer J. S., "A Proposal to Avert the Revenue Loss from 'Disincorporation,'” Tax Notes, July 27, 1987 36, 4, 425-428.

Buser, Stephen A., and Patrick J. Hess, "Empirical Determinants of the Relative Yields on Taxable and Tax-exempt Securities," Joumal of Financial Economics, May 1986, 17, 335-56.

Canellos, Peter C., "Corporate Tax Integration: By Design or by Default?" Tax Notes, June 8, 1987 35, 8, 999-1008.

Chamley, Christopher, and Heraklis Polemarchakis, "Assets, General Equilibrium and the Neutrality of Money," Review of Economic Studies, January 1984, 51, 1, 129-38.

Cornell, Bradford, and Kenneth French, "Taxes and the Princing of Stock Index Futures," Journal of Finance, June 1983, 38, 3, 675-94.

Duffie, Darrell, and Wayne Shafer, "Equilibrium and the Role of the Firm in Incomplete Markets," August 1986, Stanford University, manuscript.

Durand, David, "Costs of Debt and Equity Funds for Business: Trends and Problems of Measurement." In Conference on Research in Business Finance. New York: National Bureau of Economic Research, 1952, pp. 215-247.

Durand, David, "The Cost of Capital, Corporation Finance and the Theory of Investment: Comment." American Economic Review, September 1959, 49, 4, 639-55.

Fama, Eugene, "Banking in the Theory of Finance," Joumal of Monetary Economics, January 1980, 6, 1, 39-57.

Fama, Eugene, "Financial Intermediation and Price Level Control," Journal of Monetary Economics, January 1983, 12, 1, 7-28.

Hirshleifer, Jack, "Investment Decision under Uncertainty: Choice Theoretic Approaches," Quarterly Joumal of Economics, November 1964, 79, 509-36.

Hirshleifer, Jack, "Investment Decision under Uncertainty: Applications of the State Preference Approach." Quarterly Journal of Economics, May
1966, 80, 611-17.

Jackson, Thomas H.. The Logic and Limits of Bankruptcy Law. Cambridge, MA: Harvard University Press, 1986.

Jensen, Michael C., "Takeovers: Their Causes and Consequences," Journal of Economic Perspectives, Winter 1988, 2 21-48.

Kim, E. Han, "Optimal Capital Structure in Miller's Equilibrium.” In Bhattacharya, Sudipto, and George Constantinides, eds., Frontiers of Financial Theory. Totowa, NJ: Rownan and Littlefield, forthcoming 1988.

Lintner, John, "The Valuation of Risk Assets and the Selection of Risky Investments in Stock Portfolios and Capital Budgets," Review of Economics and Statistics, February 1965, 47, 13-37.

Merton, Robert C., "Capital Market Theory and the Pricing of Financial Securities." In Friedman, Benjamin, and Frank Hahn, eds., Handbook of Monetary Economics. Amsterdam: North Holland, forthcoming.

Merton, Robert C., "On the Pricing of Corporate Debt: The Risk of Interest Rates," Journal of Finance, May 1974, 29, 3, 449-70.

Miller, Merton H. "The Corporate Income Tax and Corporate Financial Policies." In Stabilization Policies, The Commission on Money and Credit. Englewood Cliffs, NJ: Prentice-Hall, 1963, pp. 381-470.

Miller, Merton H., “Debt and Taxes," Journal of Finance, May 1977, 32, 2, 261-75.

Miller, Merton H., "The Informational Content of Dividends." In Dornbusch, Ridiger, Stanley Fischer, and John Bossons, eds., Macroeconomics and Finance: Essays in Honor of Franco Modigliani. Cambridge, MA: MIT Press, 1987, pp. 37-58.

Miller, Merton H., and Franco Modigliani, "Dividend Policy, Growth and the Valuation of Shares," Journal of Business, October 1961, 34, 4, 411-33.

Miller, Merton, and Franco Modigliani, "Some Estimates of the Cost of Capital to the Utility Industry, 1954-7," American Economic Review, June 1966, 56, 3, 333-91.

Miller, Merton H., and Myron S. Scholes, "Dividends and Taxes," Journal of Financial Economics, December 1978, 6 4, 333-64.

Modigliani, Franco, "Debt, Dividend Policy, Taxes, Inflation and Market Valuation," Joumal of Finance, May 1982, 37, 2, 255-73.

Modigliani, Franco, and Merton H. Miller, "The Cost of Capital, Corporation Finance and the Theory of Investment," American Economic Re- 
view, June 1958, 48, 3, 261-97.

Modigliani, Franco, and Merton H. Miller, "The Cost of Capital, Corporation Finance and the Theory of Investment: Reply," American Economic Review, September 1959, 49, 4, 655-69.

Modigliani, Franco, and Merton H. Miller, "Corporate Income Taxes and the Cost of Capital: A Correction," American Economic Review, June 1963, 53, 3, 433-43.

Ross, Stephen, "The Determination of Financial Structure: The Incentive Signalling Approach," Bell Journal of Economics, Spring 1977, 8, 1, 23-40.

Ross, Stephen, "Return, Risk and Arbitrage." In Friend, Irwin, and James Bicksler, eds., Risk and Return in Finance, Vol. 1 Cambridge, MA: Ballinger, 1976, pp. 189-219.

Rubinstein, Mark, "Derivative Assets Analysis," Journal of Economic Perspectives, Fall 1987, 1, 73-93.

Sargent, Thomas J., and Bruce D. Smith, “The Irrelevance of Government Foreign Exchange Operations," 1986, The Hoover Institution, manuscript.
Sharpe, William F., "Capital Asset Prices: A Theory of Market Equilibrium under Conditions of Risk," Journal of Finance, September 1964, 19, 425-42.

Spence, Michael, "Job Market Signalling," Quarterly Joumal of Economics, August 1973, 87, 3, 355-79.

Stiglitz, Joseph, "A Re-Examination of the Modigliani-Miller Theorem," American Economic Review, December 1969, 59, 5, 784-93.

Stiglitz, Joseph, "On the Irrelevance of Corporate Financial Policy," American Economic Review, December 1974, 64, 6, 851-66.

Stiglitz, Joseph, "Information and Capital Markets." In Sharpe, William F., and Cathryn Cootner, eds., Financial Economics: Essays in Honor of Paul Cootner. Englewood Cliffs, NJ: PrenticeHall, 1982, pp. 118-58.

Stoll, Hans R., "The Relationship Between Put and Call Option Prices," Joumal of Finance, December 1969, 24, 5, 801-24.

Wallace, Neil, "A Modigliani-Miller Theorem for Open Market Operations," American Economic Review, June 1981, 71, 5, 267-74. 
http://www.jstor.org

\title{
LINKED CITATIONS
}

- Page 1 of 6 -

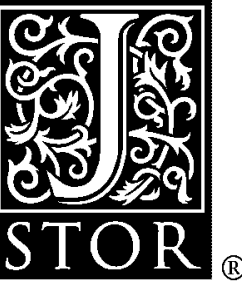

You have printed the following article:

\section{The Modigliani-Miller Propositions After Thirty Years}

Merton H. Miller

The Journal of Economic Perspectives, Vol. 2, No. 4. (Autumn, 1988), pp. 99-120.

Stable URL:

http://links.jstor.org/sici?sici=0895-3309\%28198823\%292\%3A4\%3C99\%3ATMPATY\%3E2.0.CO\%3B2-V

This article references the following linked citations. If you are trying to access articles from an off-campus location, you may be required to first logon via your library web site to access JSTOR. Please visit your library's website or contact a librarian to learn about options for remote access to JSTOR.

\section{[Footnotes]}

\author{
${ }^{1}$ Taxes and the Pricing of Stock Index Futures \\ Bradford Cornell; Kenneth R. French \\ The Journal of Finance, Vol. 38, No. 3. (Jun., 1983), pp. 675-694. \\ Stable URL: \\ http://links.jstor.org/sici?sici=0022-1082\%28198306\%2938\%3A3\%3C675\%3ATATPOS\%3E2.0.CO\%3B2-D

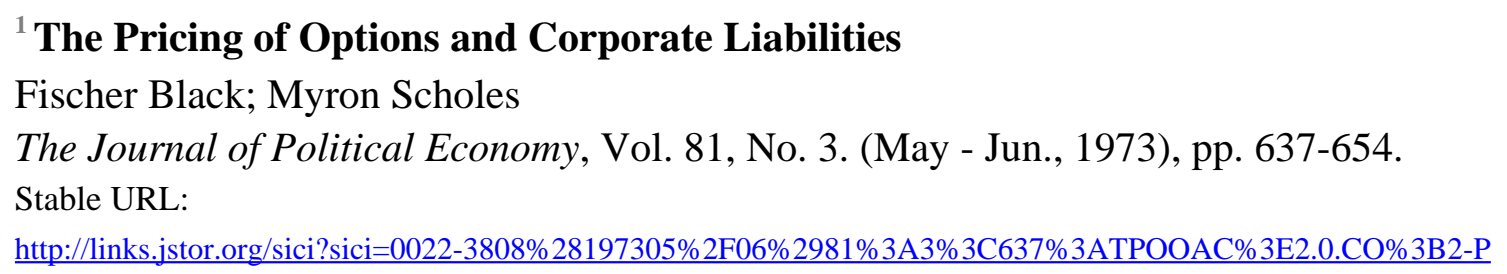

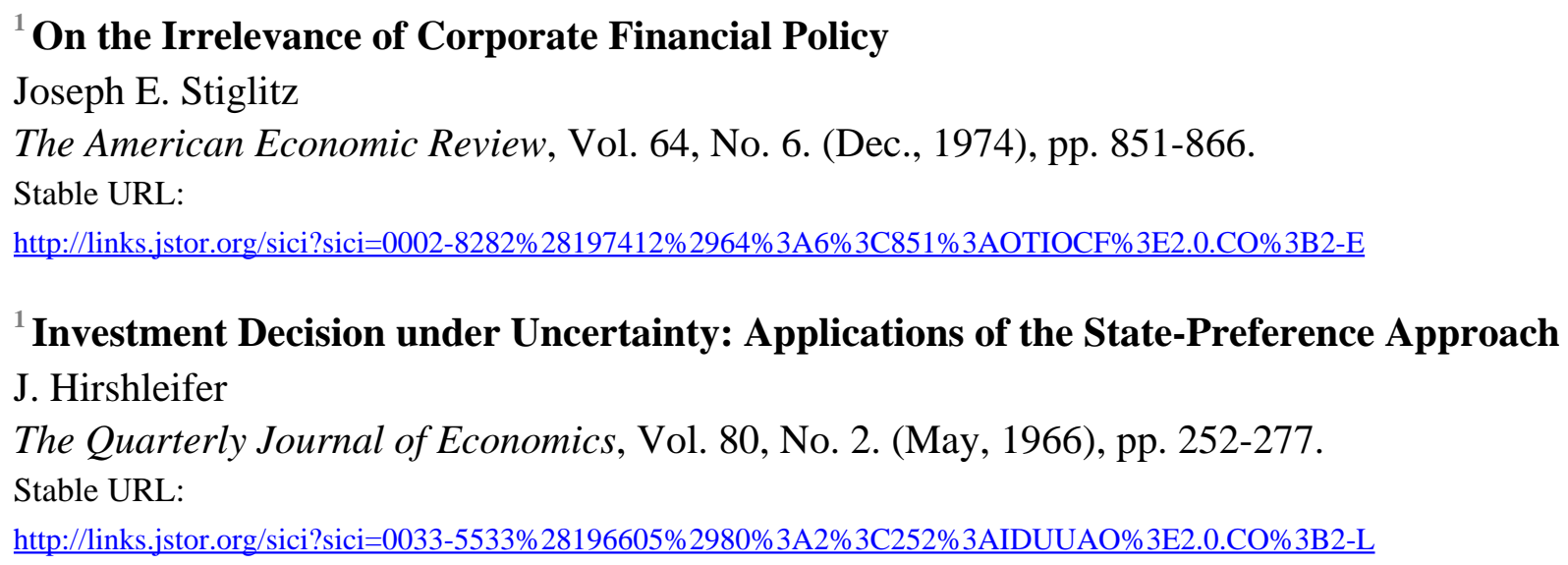

NOTE: The reference numbering from the original has been maintained in this citation list. 
http://www.jstor.org

\title{
LINKED CITATIONS
}

- Page 2 of 6 -

\section{${ }^{2}$ A Modigliani-Miller Theorem for Open-Market Operations}

Neil Wallace

The American Economic Review, Vol. 71, No. 3. (Jun., 1981), pp. 267-274.

Stable URL:

http://links.jstor.org/sici?sici=0002-8282\%28198106\%2971\%3A3\%3C267\%3AAMTFOO\%3E2.0.CO\%3B2-N

\author{
${ }^{2}$ Assets, General Equilibrium and the Neutrality of Money \\ Christophe Chamley; Herakles Polemarchakis \\ The Review of Economic Studies, Vol. 51, No. 1. (Jan., 1984), pp. 129-138. \\ Stable URL: \\ http://links.jstor.org/sici?sici=0034-6527\%28198401\%2951\%3A1\%3C129\%3AAGEATN\%3E2.0.CO\%3B2-R
}

\author{
${ }^{7}$ Takeovers: Their Causes and Consequences \\ Michael C. Jensen \\ The Journal of Economic Perspectives, Vol. 2, No. 1. (Winter, 1988), pp. 21-48. \\ Stable URL: \\ http://links.jstor.org/sici?sici=0895-3309\%28198824\%292\%3A1\%3C21\%3ATTCAC\%3E2.0.CO\%3B2-N
}

\section{References}

\author{
Valuing Corporate Securities: Some Effects of Bond Indenture Provisions \\ Fischer Black; John C. Cox \\ The Journal of Finance, Vol. 31, No. 2, Papers and Proceedings of the Thirty-Fourth Annual \\ Meeting of the American Finance Association Dallas, Texas December 28-30, 1975. (May, 1976), \\ pp. 351-367. \\ Stable URL: \\ http://links.jstor.org/sici?sici=0022-1082\%28197605\%2931\%3A2\%3C351\%3AVCSSEO\%3E2.0.CO\%3B2-Z
}

\section{The Pricing of Options and Corporate Liabilities}

Fischer Black; Myron Scholes

The Journal of Political Economy, Vol. 81, No. 3. (May - Jun., 1973), pp. 637-654.

Stable URL:

http://links.jstor.org/sici?sici=0022-3808\%28197305\%2F06\%2981\%3A3\%3C637\%3ATPOOAC\%3E2.0.CO\%3B2-P

NOTE: The reference numbering from the original has been maintained in this citation list. 
http://www.jstor.org

\title{
LINKED CITATIONS
}

- Page 3 of 6 -

\author{
Assets, General Equilibrium and the Neutrality of Money \\ Christophe Chamley; Herakles Polemarchakis \\ The Review of Economic Studies, Vol. 51, No. 1. (Jan., 1984), pp. 129-138. \\ Stable URL: \\ http://links.jstor.org/sici?sici=0034-6527\%28198401\%2951\%3A1\%3C129\%3AAGEATN\%3E2.0.CO\%3B2-R
}

Taxes and the Pricing of Stock Index Futures

Bradford Cornell; Kenneth R. French

The Journal of Finance, Vol. 38, No. 3. (Jun., 1983), pp. 675-694.

Stable URL:

http://links.jstor.org/sici?sici=0022-1082\%28198306\%2938\%3A3\%3C675\%3ATATPOS\%3E2.0.CO\%3B2-D

The Cost of Capital, Corporation Finance, and the Theory of Investment: Comment

David Durand

The American Economic Review, Vol. 49, No. 4. (Sep., 1959), pp. 639-655.

Stable URL:

http://links.jstor.org/sici?sici=0002-8282\%28195909\%2949\%3A4\%3C639\%3ATCOCCF\%3E2.0.CO\%3B2-N

\section{Investment Decision Under Uncertainty: Choice-Theoretic Approaches}

J. Hirshleifer

The Quarterly Journal of Economics, Vol. 79, No. 4. (Nov., 1965), pp. 509-536.

Stable URL:

http://links.jstor.org/sici?sici=0033-5533\%28196511\%2979\%3A4\%3C509\%3AIDUUCA\%3E2.0.CO\%3B2-Z

Investment Decision under Uncertainty: Applications of the State-Preference Approach

J. Hirshleifer

The Quarterly Journal of Economics, Vol. 80, No. 2. (May, 1966), pp. 252-277.

Stable URL:

http://links.jstor.org/sici?sici=0033-5533\%28196605\%2980\%3A2\%3C252\%3AIDUUAO\%3E2.0.CO\%3B2-L

\section{Takeovers: Their Causes and Consequences}

Michael C. Jensen

The Journal of Economic Perspectives, Vol. 2, No. 1. (Winter, 1988), pp. 21-48.

Stable URL:

http://links.jstor.org/sici?sici=0895-3309\%28198824\%292\%3A1\%3C21\%3ATTCAC\%3E2.0.CO\%3B2-N

NOTE: The reference numbering from the original has been maintained in this citation list. 
http://www.jstor.org

\section{LINKED CITATIONS}

- Page 4 of 6 -

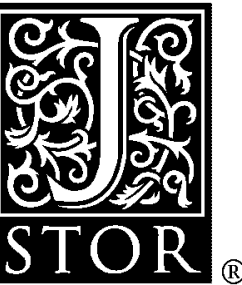

The Valuation of Risk Assets and the Selection of Risky Investments in Stock Portfolios and Capital Budgets

John Lintner

The Review of Economics and Statistics, Vol. 47, No. 1. (Feb., 1965), pp. 13-37.

Stable URL:

http://links.jstor.org/sici?sici=0034-6535\%28196502\%2947\%3A1\%3C13\%3ATVORAA\%3E2.0.CO\%3B2-7

On the Pricing of Corporate Debt: The Risk Structure of Interest Rates

Robert C. Merton

The Journal of Finance, Vol. 29, No. 2, Papers and Proceedings of the Thirty-Second Annual

Meeting of the American Finance Association, New York, New York, December 28-30, 1973.

(May, 1974), pp. 449-470.

Stable URL:

http://links.jstor.org/sici?sici=0022-1082\%28197405\%2929\%3A2\%3C449\%3AOTPOCD\%3E2.0.CO\%3B2-\%23

\section{Debt and Taxes}

Merton H. Miller

The Journal of Finance, Vol. 32, No. 2, Papers and Proceedings of the Thirty-Fifth Annual Meeting of the American Finance Association, Atlantic City, New Jersey, September 16-18, 1976. (May, 1977), pp. 261-275.

Stable URL:

http://links.jstor.org/sici?sici=0022-1082\%28197705\%2932\%3A2\%3C261\%3ADAT\%3E2.0.CO\%3B2-D

\section{Dividend Policy, Growth, and the Valuation of Shares}

Merton H. Miller; Franco Modigliani

The Journal of Business, Vol. 34, No. 4. (Oct., 1961), pp. 411-433.

Stable URL:

http://links.jstor.org/sici?sici=0021-9398\%28196110\%2934\%3A4\%3C411\%3ADPGATV\%3E2.0.CO\%3B2-A

\section{Some Estimates of the Cost of Capital to the Electric Utility Industry, 1954-57}

Merton H. Miller; Franco Modigliani

The American Economic Review, Vol. 56, No. 3. (Jun., 1966), pp. 333-391.

Stable URL:

http://links.jstor.org/sici?sici=0002-8282\%28196606\%2956\%3A3\%3C333\%3ASEOTCO\%3E2.0.CO\%3B2-4

NOTE: The reference numbering from the original has been maintained in this citation list. 
http://www.jstor.org

\section{LINKED CITATIONS}

- Page 5 of 6 -

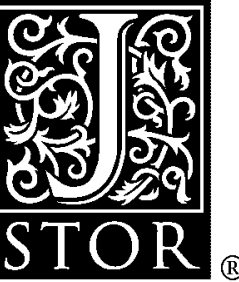

\section{Debt, Dividend Policy, Taxes, Inflation and Market Valuation}

Franco Modigliani

The Journal of Finance, Vol. 37, No. 2, Papers and Proceedings of the Fortieth Annual Meeting of the American Finance Association, Washington, D.C., December 28-30, 1981. (May, 1982), pp. 255-273.

Stable URL:

http://links.jstor.org/sici?sici=0022-1082\%28198205\%2937\%3A2\%3C255\%3ADDPTIA\%3E2.0.CO\%3B2-G

\section{The Cost of Capital, Corporation Finance and the Theory of Investment}

Franco Modigliani; Merton H. Miller

The American Economic Review, Vol. 48, No. 3. (Jun., 1958), pp. 261-297.

Stable URL:

http://links.jstor.org/sici?sici=0002-8282\%28195806\%2948\%3A3\%3C261\%3ATCOCCF\%3E2.0.CO\%3B2-3

The Cost of Capital, Corporation Finance, and the Theory of Investment: Reply

Franco Modigliani; Merton H. Miller

The American Economic Review, Vol. 49, No. 4. (Sep., 1959), pp. 655-669.

Stable URL:

http://links.jstor.org/sici?sici=0002-8282\%28195909\%2949\%3A4\%3C655\%3ATCOCCF\%3E2.0.CO\%3B2-L

\section{Corporate Income Taxes and the Cost of Capital: A Correction}

Franco Modigliani; Merton H. Miller

The American Economic Review, Vol. 53, No. 3. (Jun., 1963), pp. 433-443.

Stable URL:

http://links.jstor.org/sici?sici=0002-8282\%28196306\%2953\%3A3\%3C433\%3ACITATC\%3E2.0.CO\%3B2-G

\section{Derivative Assets Analysis}

Mark Rubinstein

The Journal of Economic Perspectives, Vol. 1, No. 2. (Autumn, 1987), pp. 73-93.

Stable URL:

http://links.jstor.org/sici?sici=0895-3309\%28198723\%291\%3A2\%3C73\%3ADAA\%3E2.0.CO\%3B2-M

\section{Capital Asset Prices: A Theory of Market Equilibrium under Conditions of Risk}

William F. Sharpe

The Journal of Finance, Vol. 19, No. 3. (Sep., 1964), pp. 425-442.

Stable URL:

http://links.jstor.org/sici?sici=0022-1082\%28196409\%2919\%3A3\%3C425\%3ACAPATO\%3E2.0.CO\%3B2-O

NOTE: The reference numbering from the original has been maintained in this citation list. 
http://www.jstor.org

\section{LINKED CITATIONS \\ - Page 6 of 6 -}

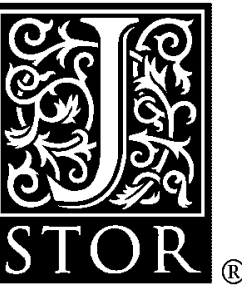

\section{Job Market Signaling}

Michael Spence

The Quarterly Journal of Economics, Vol. 87, No. 3. (Aug., 1973), pp. 355-374.

Stable URL:

http://links.jstor.org/sici?sici=0033-5533\%28197308\%2987\%3A3\%3C355\%3AJMS\%3E2.0.CO\%3B2-3

\section{A Re-Examination of the Modigliani-Miller Theorem}

Joseph E. Stiglitz

The American Economic Review, Vol. 59, No. 5. (Dec., 1969), pp. 784-793.

Stable URL:

http://links.jstor.org/sici?sici=0002-8282\%28196912\%2959\%3A5\%3C784\%3AAROTMT\%3E2.0.CO\%3B2-9

\section{On the Irrelevance of Corporate Financial Policy}

Joseph E. Stiglitz

The American Economic Review, Vol. 64, No. 6. (Dec., 1974), pp. 851-866.

Stable URL:

http://links.jstor.org/sici?sici=0002-8282\%28197412\%2964\%3A6\%3C851\%3AOTIOCF\%3E2.0.CO\%3B2-E

\section{The Relationship Between Put and Call Option Prices}

Hans R. Stoll

The Journal of Finance, Vol. 24, No. 5. (Dec., 1969), pp. 801-824.

Stable URL:

http://links.jstor.org/sici?sici=0022-1082\%28196912\%2924\%3A5\%3C801\%3ATRBPAC\%3E2.0.CO\%3B2-S

\section{A Modigliani-Miller Theorem for Open-Market Operations}

Neil Wallace

The American Economic Review, Vol. 71, No. 3. (Jun., 1981), pp. 267-274.

Stable URL:

http://links.jstor.org/sici?sici=0002-8282\%28198106\%2971\%3A3\%3C267\%3AAMTFOO\%3E2.0.CO\%3B2-N

NOTE: The reference numbering from the original has been maintained in this citation list. 